\title{
Streptococcus gallolyticus endocarditis- an uncommon but serious complication of constipation management
}

Hong Kong Med J 2019;25:257

http://doi.org/10.12809/hkmj197978

To the Editor-I deeply appreciate the timely publication of the Consensus Statement on Chronic Idiopathic Constipation in the current issue of the Hong Kong Medical Journal (April 2019). ${ }^{1}$ It addressed many important issues, including advising caution on the popular use of fibre-rich supplements and lactulose. These compounds are indigestible for humans and serve as osmotic bulk expanders to facilitate faecal transit and expulsion. They are fermented by intestinal bacteria, often but not always favouring beneficial bacteria such as bifidobacteria over unfavourable bacteria such as clostridia and bacteroides. For decades, health food advocates focused on their value and seldom cautioned against any risks. ${ }^{2}$ However, the survival advantage might change, and allow opportunistic pathogens to thrive. ${ }^{3}$ Streptococcus gallolyticus is an example of such an opportunist. First, it is capable of digesting a wide range of plant cellulose and disaccharides, including lactulose. Second, it creates a highly acidic local environment deleterious to many other organisms but not to itself, having developed various pathways to survive such acidity. Third, it attains virulence with Pil-3 and other molecules, which enable it to infect intestinal mucosal cells, to evade host innate immunity, and to enter the bloodstream, whereupon it readily attaches to collagen-rich tissues such as heart valves resulting in endocarditis. ${ }^{4}$ For a patient with chronic constipation, the long-term intake of a high-fibre diet and lactulose has been found associated with Streptococcus gallolyticus endocarditis. $^{5}$

\section{Author contributions}

The author had full access to the data, contributed to the study, approved the final version for publication, and take responsibility for its accuracy and integrity.

\section{Conflicts of interest}

The author has no conflicts of interest to disclose

\section{Funding/support}

This letter received no specific grant from any funding agency in the public, commercial, or not-for-profit sectors.

John SM Leung *, FCSHK, FHKAM (Surgery)

Department of Cardiothoracic Surgery, St Paul's Hospital, Causeway Bay, Hong Kong

*Corresponding author: leungsiumanjohn@yahoo.com.hk

\section{References}

1. Wu JC, Chan AO, Cheung TK, et al. Consensus statement on diagnosis and management of chronic idiopathic constipation in adults in Hong Kong. Hong Kong Med J 2019;25:142-8.

2. Simpson HL, Campbell BJ. Review article: dietary fibre-microbiota interactions. Aliment Pharmacol Ther 2015;42:158-79.

3. Montagne L, Pluske JR, Hampston DJ. A review of interactions between dietary fibre and the intestinal mucosa, and their consequences on digestive health in young, non-ruminant animals. Anim Feed Sci Technol 2003;108:95-117.

4. Hensler ME. Streptococcus gallolyticus, infective endocarditis, and colon carcinoma: new light on an intriguing coincidence. J Infect Dis 2011;203:1040-2.

5. Rusniok C, Couvé E, Da Cunha V, et al. Genome sequence of Streptococcus gallolyticus: insights into its adaptation to the bovine rumen and its ability to cause endocarditis. J Bacteriol 2010;192:2266-76. 